$1-1-1967$

\title{
Effects of time of summer pruning on limb development and shoot growth of five geographic origins of Scotch pine
}

James H. Brown

Follow this and additional works at: https://researchrepository.wvu.edu/ wv_agricultural_and_forestry_experiment_station_bulletins

\section{Digital Commons Citation}

Brown, James H., "Effects of time of summer pruning on limb development and shoot growth of five geographic origins of Scotch pine" (1967). West Virginia Agricultural and Forestry Experiment Station Bulletins. 543.

https://researchrepository.wvu.edu/wv_agricultural_and_forestry_experiment_station_bulletins/497 @ WVU. It has been accepted for inclusion in West Virginia Agricultural and Forestry Experiment Station Bulletins by an authorized administrator of

The Research Repository @ WVU. For more information, please contact ian.harmon@mail.wvu.edu. 
West Virginia University Libraries

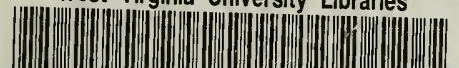

30802

308021009521343 


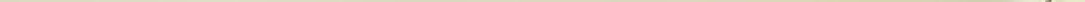




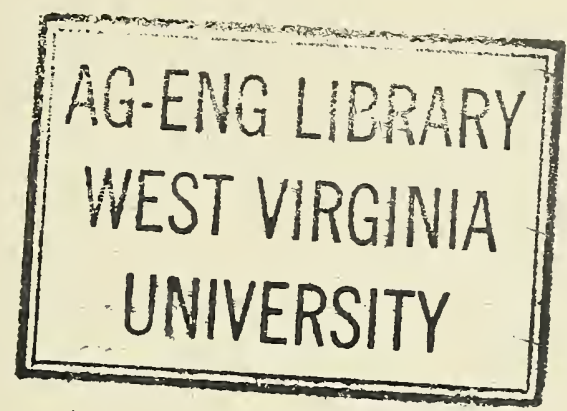

Lffects of Time of Summer Pruning in Limb Development and Shoot Growth of Five Geographic Origins of Scotch Pine
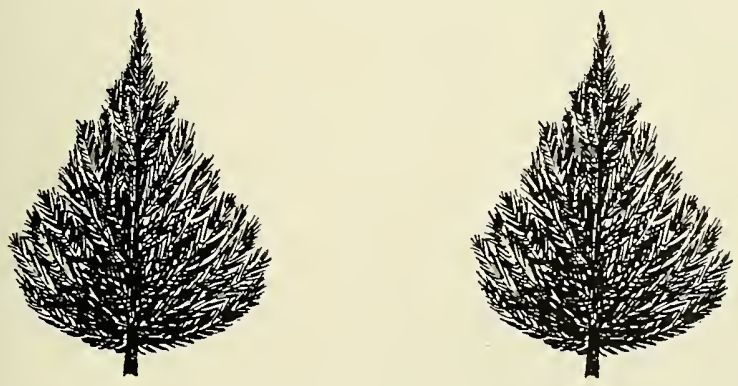

WEST VIRGINA UNIVERSITY AGRICULTURAL EXPERIMENT STATION BULLETIN 543 MARCH 1967 



\section{Effects of Time of Summer Pruning On Limb Development and Shoot Growth Of Five Geographic Origins of Scotch Pine}

JAMES H. BROWN

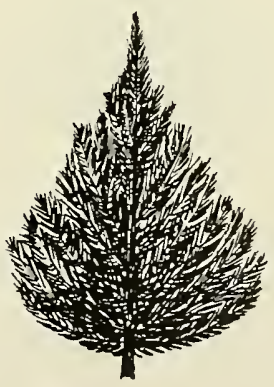




\section{THE AUTHOR}

James H. Brown is Assistant Silviculturist.

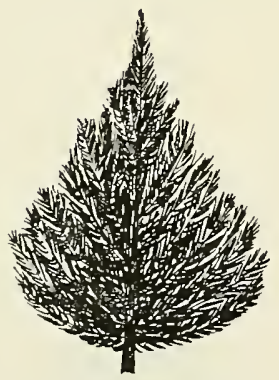

West Virginia University

Agricultural Experiment Station

College of Agriculture and Forestry

A. H. Vanlandingham, Director

Morgantown 


\title{
Effects of Time of Summer Pruning On Limb Development and Shoot Growth Of Five Geographic Origins of Scotch Pine
}

\author{
JAMES H. BROWN
}

In recent years the use of Scotch pine (Pinus sylvestris L.) for Christmas trees has been increasing steadily. In 1960 the species contributed approximately 17 per cent of the total number of trees used in this country, ranking second behind Douglas-fir which contributed 23 per cent of the total (Sowder, 1961). In 1962 Scotch pine for the first time was the leading contributor of Christmas tree sales, with over 7 million trees harvested, or approximately 21 per cent of the total (Sowder, 1963), and by 1964 the figure had risen to over 9 million trees and 27 per cent of the total. Essentially all Scotch pine harvested for Christmas trees comes from plantations established exclusively or primarily for use as Christmas trees, while nearly all Douglas-fir harvested comes from natural or wild stands.

Scotch pine is native over a wide geographic area in Europe and Asia, reaching from above the Arctic Circle in the north to Spain and Turkey in the south, and from Scotland in the west nearly to the Pacific Ocean in the east. Within this extensive range, rather distinct patterns of variation in the species exist. Wright and Bull (1963) recognized at least 14 geographic ecotypes of Scotch pine, differing in such characteristics as needle length, growth rate, winter foliage coloration, length of growing season, and other characters.

After an initial establishment period of one to four years after planting, during which seedlings are developing an extensive root system, Scotch pine usually grows so rapidly that long internodes between whorls of limbs and laterals of varying length give the trees an irregular appearance (Figure 1). Without pruning or shearing ${ }^{1}$ it is probable that only 30 to 40 per cent of those trees planted will be of saleable quality, whereas with shearing the number of saleable trees can be increased to 80 or 90 per cent of the total planted (Figure 2). It has been demonstrated by a number of studies that results of pruning may vary con-

In this bulletin the terms shearing and pruning are used interchangeably with no distinction between the two. 
siderably, depending upon the time of year when shearing was carried out (Brown, 1960; Brown, 1964; and Larsson, 1961).

In the study by Brown (1964) it was shown that results of pruning during the summer also may vary considerably, depending on differ-

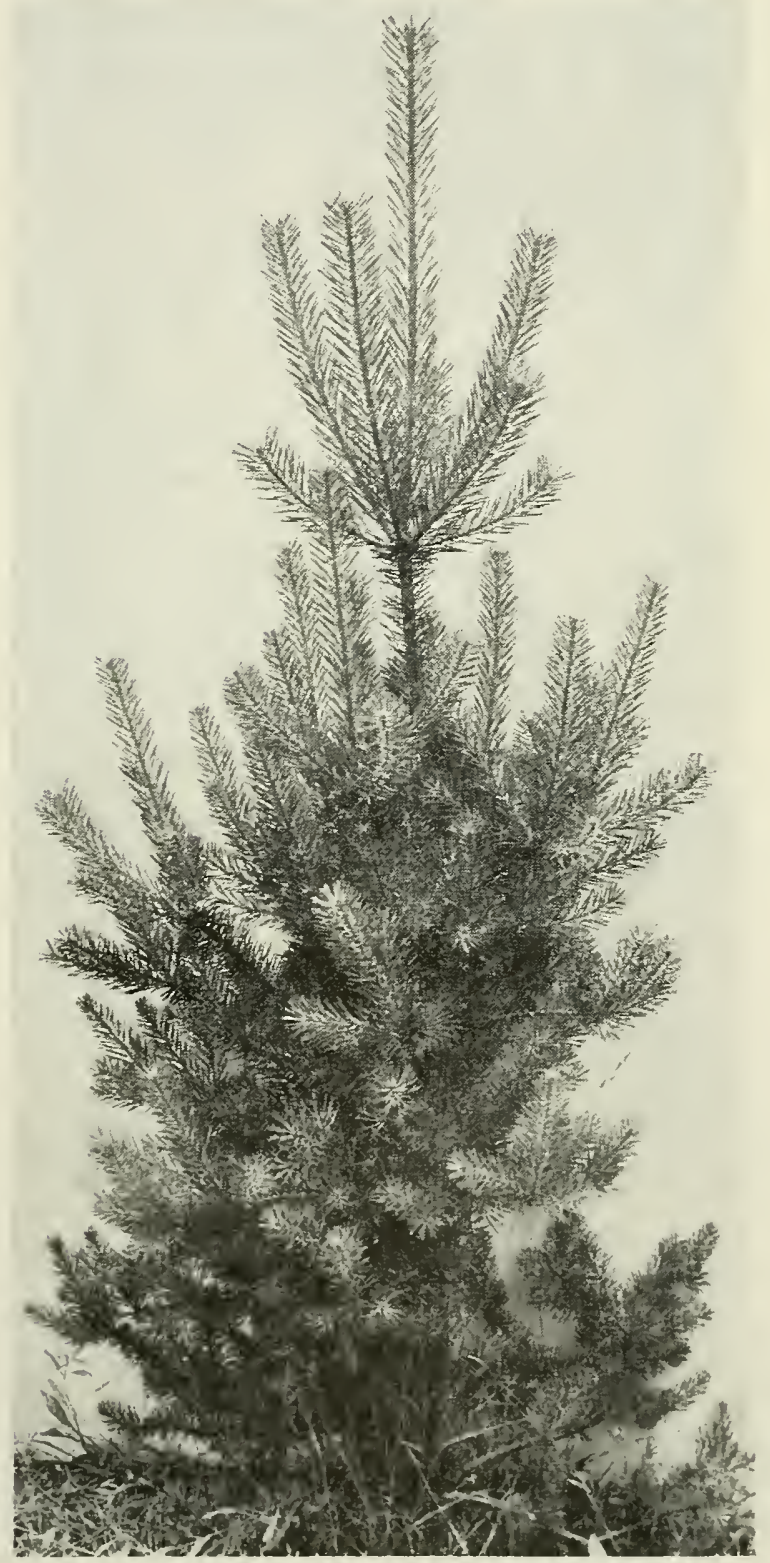

FIGURE 1

Unpruned Scotch pine, showing open irregular appearance of the tree caused by variations in density and laterals of varying lengths. 
FIGURE 2

Pruned Scotch pine, showing that irregularities in density and outline have bee $n$ regulated by shearing to give an even, conicalshaped tree.

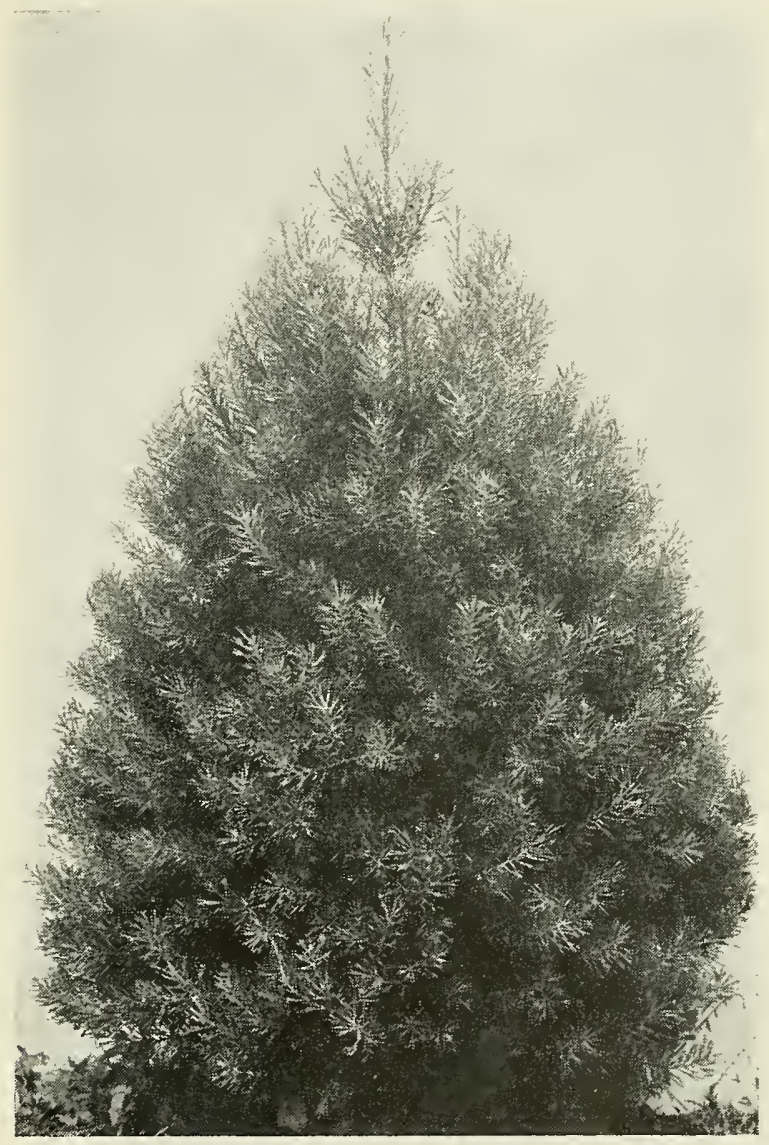

ences in temperature and precipitation from one growing season to another. Since there is such a great diversity in the range and characteristics of Scotch pine, it seemed probable that the different ecotypes or races might also react differently to various cultural treatments, especially pruning. The purpose of the study reported here was to determine if differences could be detected in the results from pruning Scotch pine of different geographic origins at different times during the summer.

\section{PROCEDURE}

The plantation used in this study is located near Keysers Ridge in Garrett County, Maryland. The trees were planted in the spring of 1956 using plants grown from seed obtained from stands of five origins in Europe, as indicated in Table 1. Although exact data concerning elevation, latitude, and longitude of origin were not available for the seed, it 
was possible to link four of the sources rather closely to sources or ecotypes described by Wright and Baldwin (1957) and/or Wright and Bull (1963).

The south-Swedish source used in this study conforms closely in a number of characteristics with those of the south or south-central Scandanavian ecotypes (Ecotypes C and D) described in the above mentioned papers. The Austrian source probably originated from stands in the area of central Europe designated as Ecotype $\mathrm{G}$ in both of the above mentioned papers. The French seed source used was from the province of Haute Loire in the central Massif of France. This conforms closely to the south French Ecotype M described by Wright and Bull. The Scotch Highlands source apparently originated from the rather limited stands in Scotland, designated by Wright and Baldwin as Ecotype E and by Wright and Bull as Ecotype L.

Neither of the studies reported above had included Scotch pine of Swiss origin, so that the source used in this study could not be tied definitely to those described by Wright and Baldwin or Wright and Bull. However, characteristics of the trees, including growth rates and foliage characteristics, would indicate a type not closely related to any of the described ecotypes which immediately surround Switzerland (Ecotypes G,H,M, and J of Wright and Bull and Ecotypes G,H, and J of Wright and Baldwin). In addition, winter foliage coloration of the Swiss source trees was somewhat more yellow than any of the central European types and was much more yellow than the south French Ecotype M described by Wright and Bull. It seems probable that the Swiss source used came

TABLE 1

\section{Seed sources used in pruning study and probable correlations with known seed sources}

\begin{tabular}{|c|c|c|}
\hline \multirow{2}{*}{$\begin{array}{l}\text { Country and/or Area } \\
\text { of Origin of Trees } \\
\text { Used in Pruning Study }\end{array}$} & \multicolumn{2}{|c|}{$\begin{array}{c}\text { Probable Correlation of Source Used With Ecotype and } \\
\text { Area as Designated by: }\end{array}$} \\
\hline & Wright $\underset{(1957)}{\text { and Baldwin }}$ & Wright and Bull (1963) \\
\hline South Sweden & $\begin{array}{l}\text { Southern Scandanavia; } \\
\text { Ecotype C or D }\end{array}$ & $\begin{array}{l}\text { Southern Scandanavia; } \\
\text { Ecotype C or D }\end{array}$ \\
\hline Scottish Highlands & Scotland, Ecotype E & Scotland, Ecotype L \\
\hline Swiss Alps & Not Included in Study & Not Included in Study \\
\hline Austria & $\begin{array}{l}\text { Germany, Poland, etc., } \\
\text { Ecotype G }\end{array}$ & $\begin{array}{l}\text { Germany, Czechoslovakia, } \\
\text { etc.; Ecotype G }\end{array}$ \\
\hline France, Haute Loire & Not Included in Study & $\begin{array}{l}\text { Central Massif of France; } \\
\text { Ecotype M }\end{array}$ \\
\hline
\end{tabular}


FIGURE 3

New buds forming at the bases of needle fascicles on a pruned Scotch pine terminal.

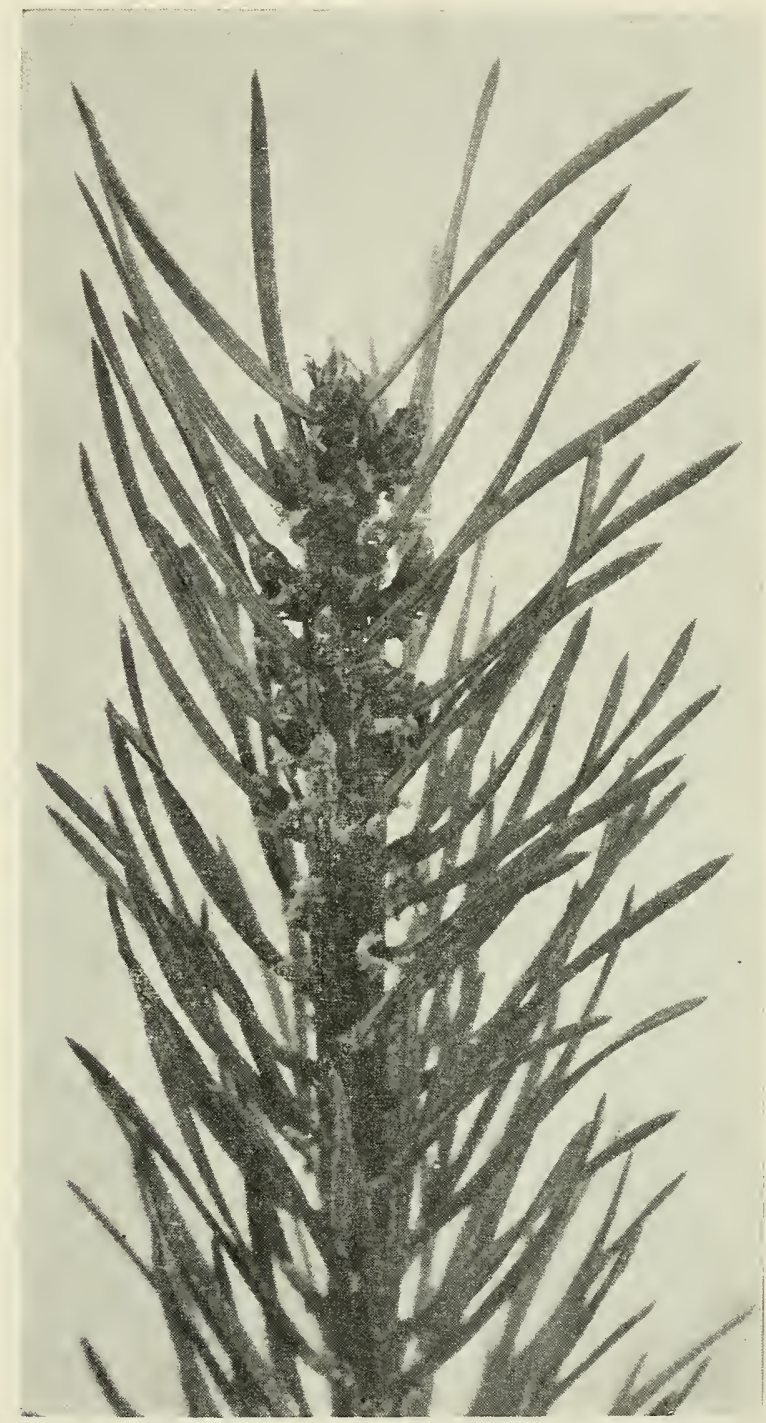

from stands in the Alps which had either been sufficiently isolated to produce a type distinctly different from those surrounding countries, or that sampling in the previous studies was insufficient to reveal any clinal trend which might exist between the described types and the one used in this particular study.

Trees from each seed source were pruned bi-monthly during the summers of 1961 and 1962, beginning in early-June and continuing until early-September. In addition, one group of trees from each seed source 
was left as unpruned controls. A split-plot experimental design with two tree plots and five replications was used, with the eight times of pruning (including controls) being the main plot effect and the five seed sources as the sub-plot. A summary of the analyses of variance for main effects and for all interactions for the variables studied is shown in Appendix Table 1.

In pruning, new terminal shoots were cut to lengths of approximately 9 to 12 inches and laterals were cut to varying lengths to produce a symmetrical and nearly cone-shaped tree. Cuts on terminals were made at angles of approximately 45 to 60 degrees in order to minimize the number of trees which developed multiple terminals (Brown, 1961). Following pruning, adventitious buds formed at the bases of needle fascicles as shown in Figure 3, and the following year new limbs-both whorl and terminal-developed from these buds.

Information was collected concerning number of buds formed, total number of limbs formed, number of effective limbs formed (those which actually contribute to the foliage density of the trees as shown in Figure 4 ), and new terminal growth on all pruned and unpruned trees. The

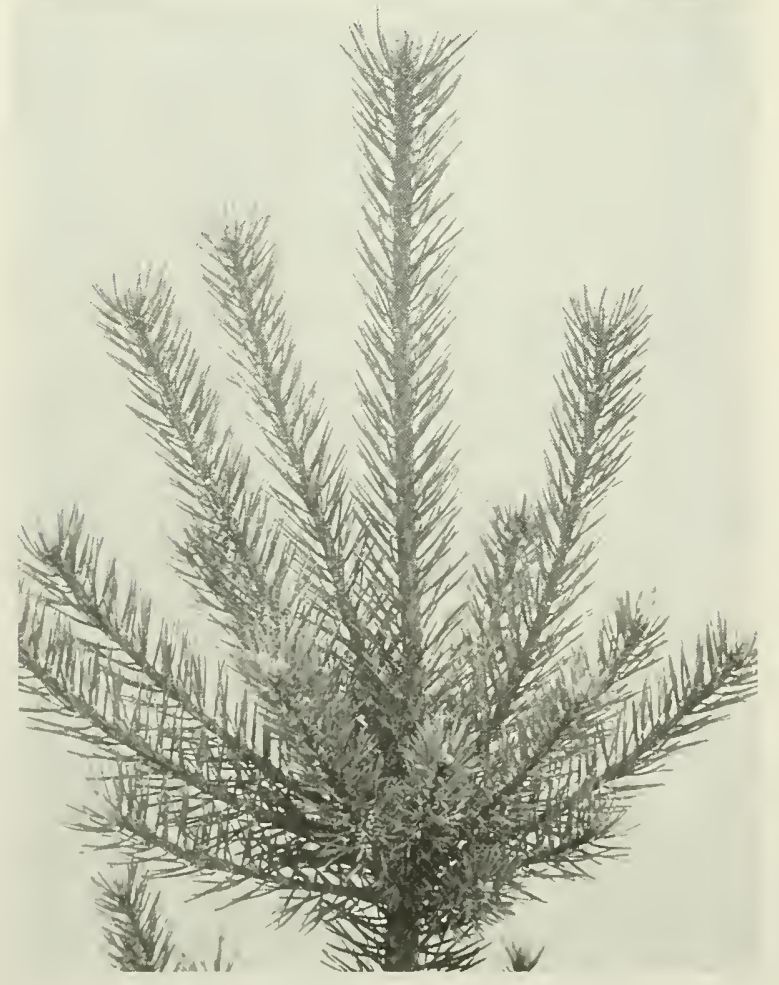

FIGURE 4

Limb development following pruning of a Scotch $p$ in e terminal, showing the presence of s e veral small limbs which will never develop sufficiently to contribute to the foliage density of the tree. 
data for number of buds were collected in the fall of the year in which pruning was carried out. Information on total number of limbs which developed from these buds and for shoot growth was taken at the end of the summer following pruning (as, for example, in September 1963 for trees sheared in 1962). Counts of number of effective limbs were made in 1964, three and two years, respectively, after the 1961 and 1962 shearings. In subsequent analyses, only the number of effective limbs and terminal growth were subjected to analyses of variance. This procedure was followed because it had been shown earlier (Brown, 1964) that these two factors were probably most important in affecting proper development of well-sheared Christmas trees. In discussions that follow, only these two factors are considered.

\section{RESULTS}

Brown (1964) showed that rather distinct patterns of bud set, limb formation and shoot growth developed on Scotch pine stems pruned at different times during the summer and that these patterns varied somewhat depending on weather conditions prevailing during the early part of the growing season. The study reported here revealed similar trends, but in addition showed that the origin of the seed can also greatly influence the patterns of limb development and shoot growth. These trends are discussed in detail in the sections that follow.

\section{Effect of Time of Pruning on Effective Limb Formation}

As shown in Table 2 and Figure 5, the number of effective limbs formed on pruned stems varied considerably depending on time of shearing during the summer. In general, numbers of limbs were greatest after early-June to mid-July prunings, and then decreased constantly as shearing was done later in the summer. The analysis of variance (Appendix Table 1) showed that these differences were highly significant. In making comparisons among all means using the Least Significant Differences (LSD) technique, it was found that the early summer prunings (earlyJune to early-July) produced significantly greater numbers of effective limbs than did prunings made later in the summer and also that these numbers were significantly greater than those on unpruned controls. Results from these early season prunings were not significantly different from each other, however. In comparing results from prunings made later in the summer (mid-July or later), significant differences were found for all possible comparisons, and in all cases except those for early-September prunings, the number of limbs were greater on pruned trees than on unpruned controls. In the case of trees pruned in September there was a 


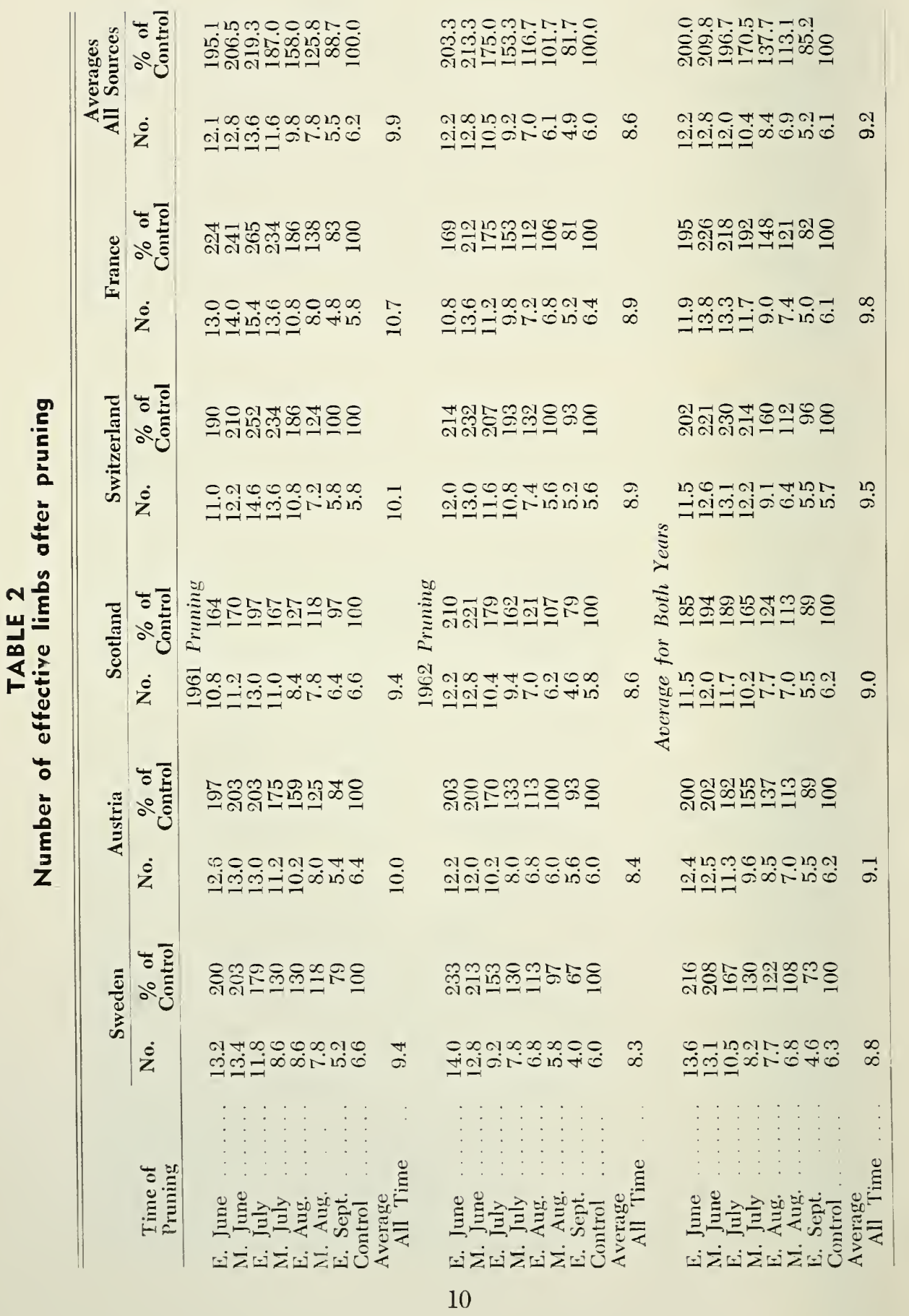


significant reduction in the number of effective limbs on pruned, as compared to control, trees.

Appendix Table 1 also shows that highly significant differences resulted from prunings of different seed sources. In making all possible comparisons among means (LSD), however, it was found that this vari-

FIGURE 5: NUMBER OF EFFECTIVE LIMBS FORMED AFTER PRUNING

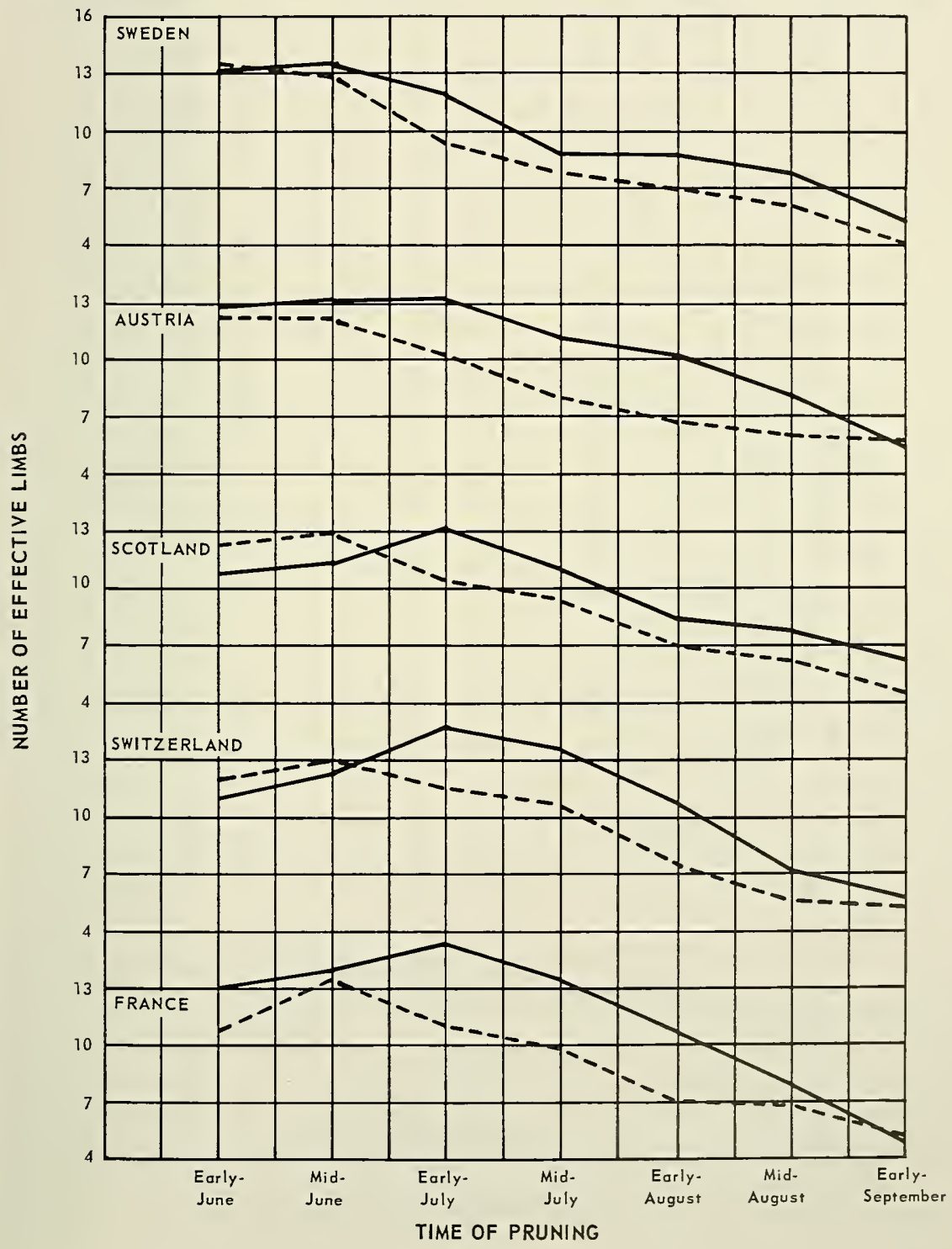




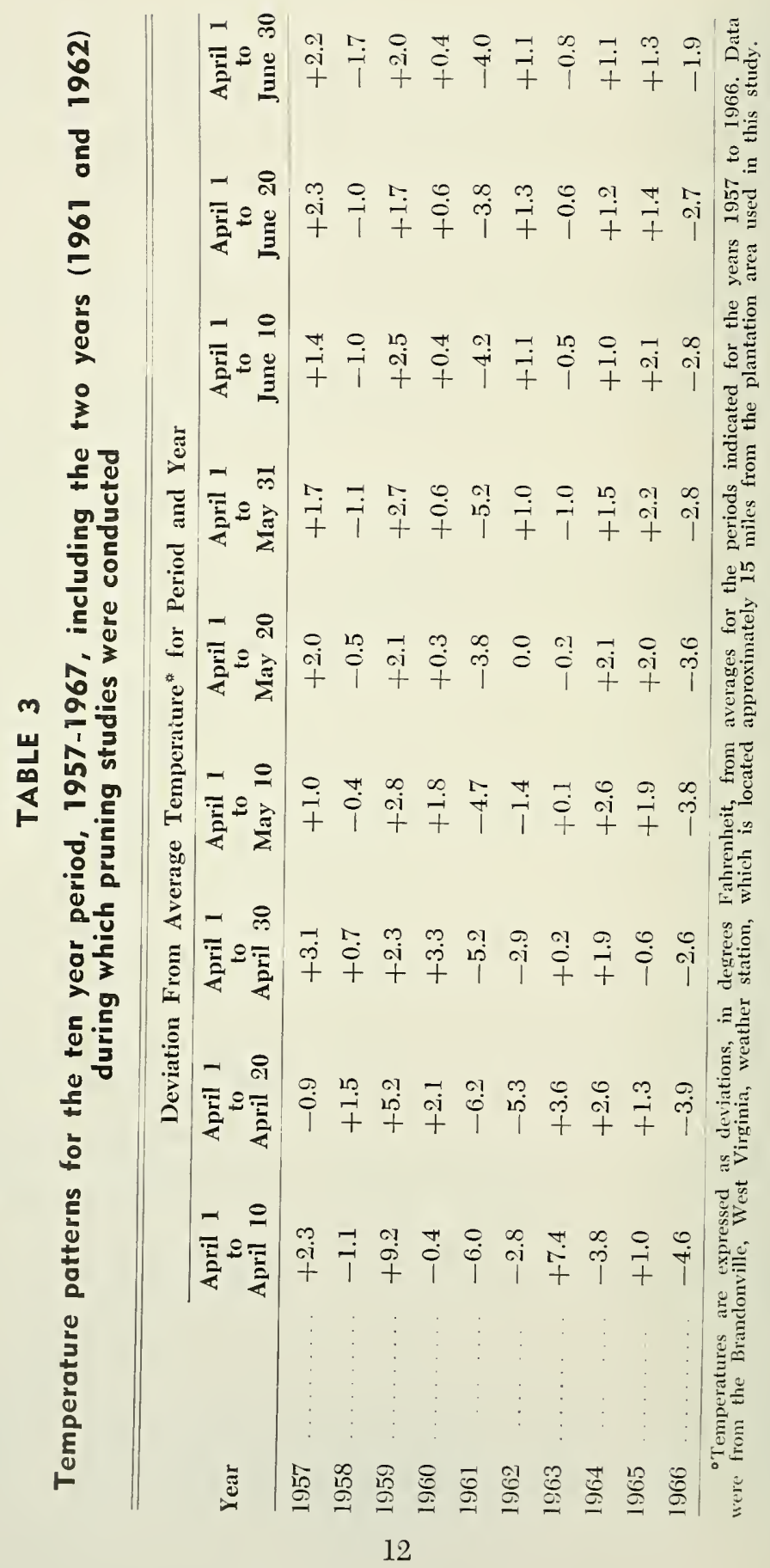


ance was due primarily to higher numbers of effective limbs formed on the two most southerly seed sources (France and Switzerland) in comparison with those from other portions of the range, particularly those from Sweden.

As shown in Appendix Table 1, results during different years can also be significantly different, with the number of effective limbs formed on pruned trees in 1961 being greater than those formed on trees pruned in 1962. Two factors can probably account for this. First, as indicated in Table 3, 1961 had a particularly late growing season and because of this, late season pruning resulted in a higher number of limbs in 1961 than in 1962. A second probable reason is that the number of effective limbs formed after first prunings is generally greater than the number formed after second prunings on the same trees (Brown, 1964). The trees used in this study received their initial prunings in 1961 and were sheared for the second time in 1962.

Of probably even more importance than comparisons of results between main effects (time of pruning, seed sources, and years) alone, is that significant time-seed source and year-time interactions were found. Thus results varied depending on the particular combination of time of pruning, seed source, and year being considered. This can be seen easily in Figure 5, where, for example, in 1961 the maximum number of effective limbs which formed on Swedish source trees was found on those pruned in early- to mid-June while on Austrian trees, maximums were essentially equal on trees pruned from early-June to mid-July. On trees of the other three sources there were definite trends of increasing numbers of effective limbs on trees pruned up to mid-July and then a decided decrease in numbers of trees pruned later in the summer. In 1962 , trends were considerably different with periods of maximum limb formation being shifted to a time from two weeks to a month earlier in the summer. As a result, maximum numbers of effective limbs were found on Swedish and Austrian trees pruned in early-June, while maximum numbers on Scottish, Swiss, and French trees were found on trees sheared in mid-June.

\section{Terminal Growth After Pruning}

Table 4 and Figure $6 \mathrm{~A}$ and $6 \mathrm{~B}$ summarize the results for terminal growth on the sheared stems of the different origins of Scotch pine. In general, development of new terminal shoots on pruned trees followed a pattern similar to that discussed previously for effective limb development, with the major exception being that maximum stem elongation vas usually found on trees pruned approximately two weeks earlier than those on which maximum numbers of limbs developed. As shown in 


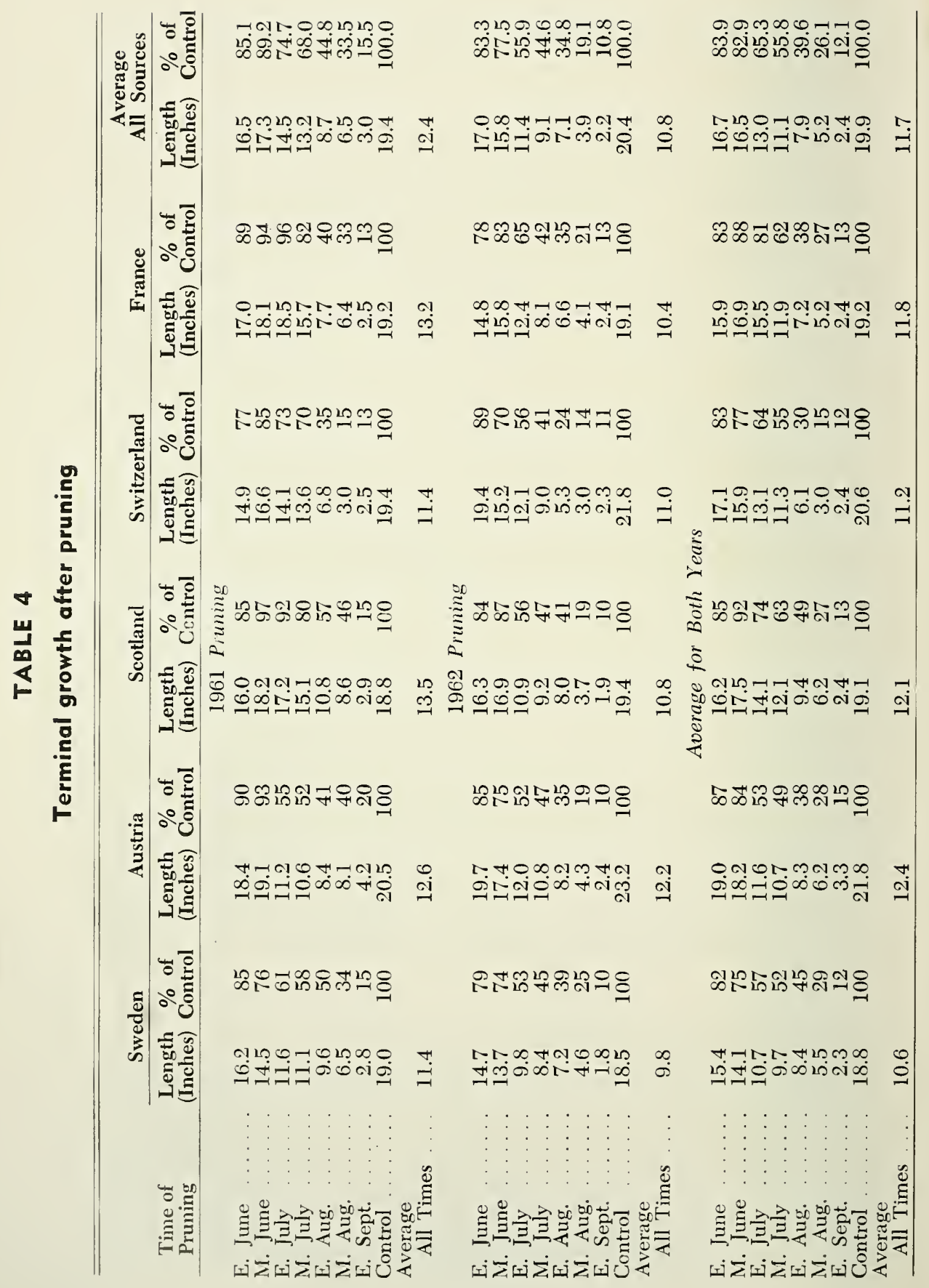


Appendix Table 1, all main effects (time of pruning, seed source, and year), as well as all interactions (time-seed source, time-year, seed source-year, and time-year-seed source), were found to give highly significant differences in results.

In making all possible comparisons (LSD) among means for different times of pruning during the summer, all differences were found to be significantly different, except for that between early- and mid-June shearings. It was also found that in every case the growth of unpruned control trees was significantly greater than that on pruned trees, with the reduction in growth being increasingly greater as trees were pruned later in the summer. For example, the growth on trees pruned in earlyJune was approximately 84 per cent as great as that on unpruned trees; that on trees sheared in mid-July was only approximately 56 per cent as great; and trees pruned in early-September had only 13 per cent as much shoot elongation as did unpruned control trees (Figure 6B).

Least significant difference comparisons of terminal growth on trees of different seed sources revealed a pattern which appears to have resulted from a combination of two factors-differences in reaction to time of pruning (seed source-time interaction) and growth rates of the sources used in the study. Maximum growth was found on the Austrian and Scottish sources, the two whose trees were largest when the study was initiated in 1961. However, the French source trees showed more shoot growth after pruning than did either the Swedish or Swiss sources, despite the fact that French source trees were the smallest at the time the study was started. Apparently greater amounts of elongation on midto late-summer pruned French source trees, as compared to that on Swiss and Swedish trees, accounted for the higher average terminal growth of the French origin.

Of importance also is the fact that the exact pattern of growth varied considerably, depending on the seed source being considered. In 1961, for example, Swedish source trees showed maximum growth on trees pruned in early-June, with a constant decrease in elongation on trees pruned progressively later in the summer. French source trees, on the other hand, showed a pattern with maximum growth on trees sheared in early-June, with declining growth on trees pruned after this time. The other three sources showed patterns which varied between these two extremes. The Austrian trees had approximately equal growth on trees pruned in early- and mid-June, with decreasing elongation after this time, while growth on Scottish and Swiss source trees increased slightly from early- to mid-June and then showed decreasing growth from later shearings. In 1962, the Swedish and Austrian source trees displayed similar patterns, with decreasing growth on trees pruned after early-June, 
while the Scottish, Swiss, and French source trees showed generally similar patterns of equal or slightly increasing growth on early- and midJune sheared trees, followed by decreasing elongation on trees pruned from early-July to early-September.

The greater growth in 1961 and in 1962 can probably also be related to a combination of factors. In part, the reduction in growth in 1962, as

FIGURE 6A: TERMINAL GROWTH AFTER PRUNING: ACTUAL GROWTH, INCHES 1962

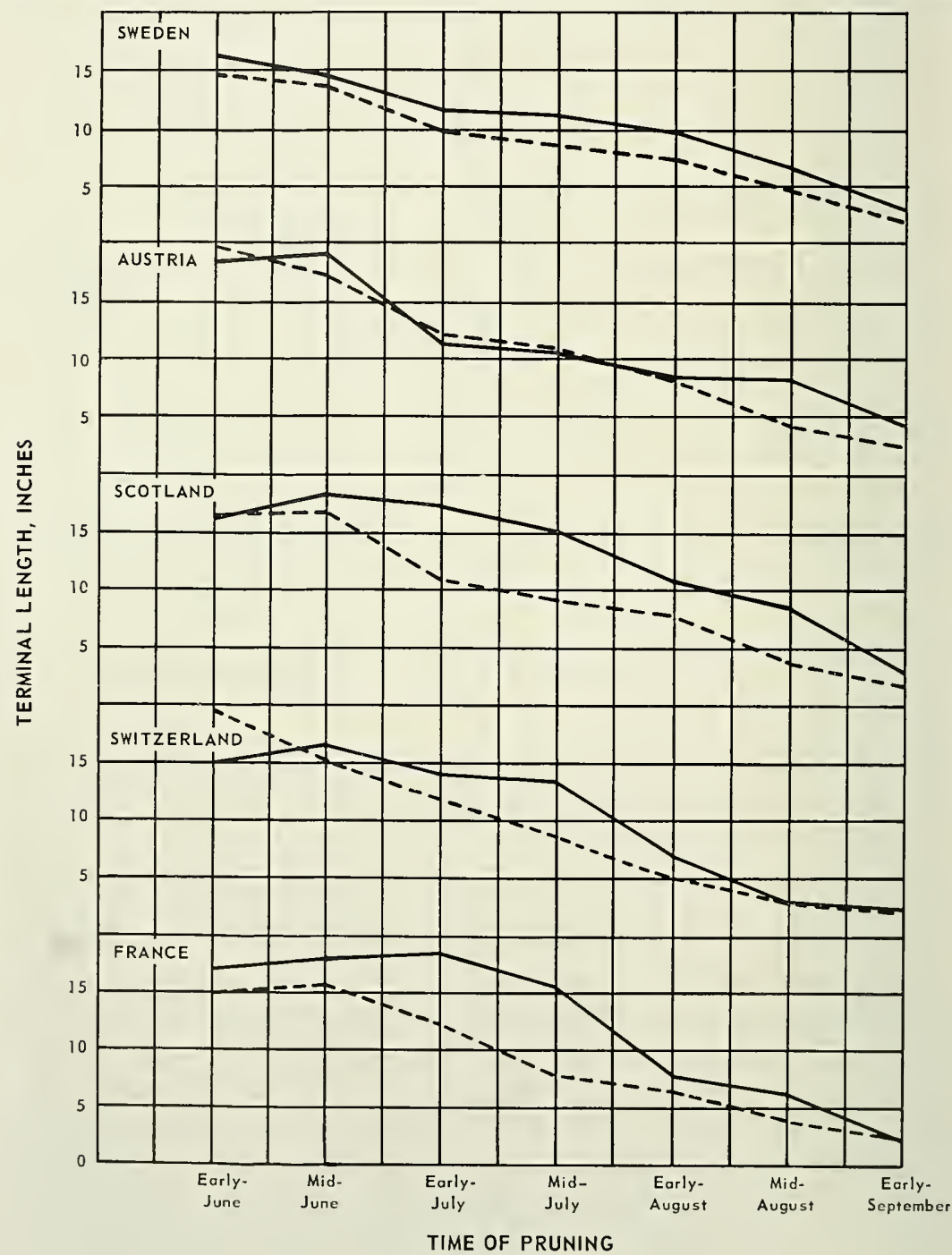


compared to 1961, can be accounted for by differences in reaction of trees the first time they are pruned as opposed to second or later shearing. As pointed out with reference to effective limb development, initial prunings can give better results than later prunings on the same trees (Brown, 1964). The second factor which appears to have contributed to the greater growth in 1961 than in 1962 is the significant differences in reactions of the various seed sources, as discussed above and as evi-

FIGURE 6B: TERMINAL GROWTH AFTER PRUNING: PER CENT OF CONTROL TREES 1962

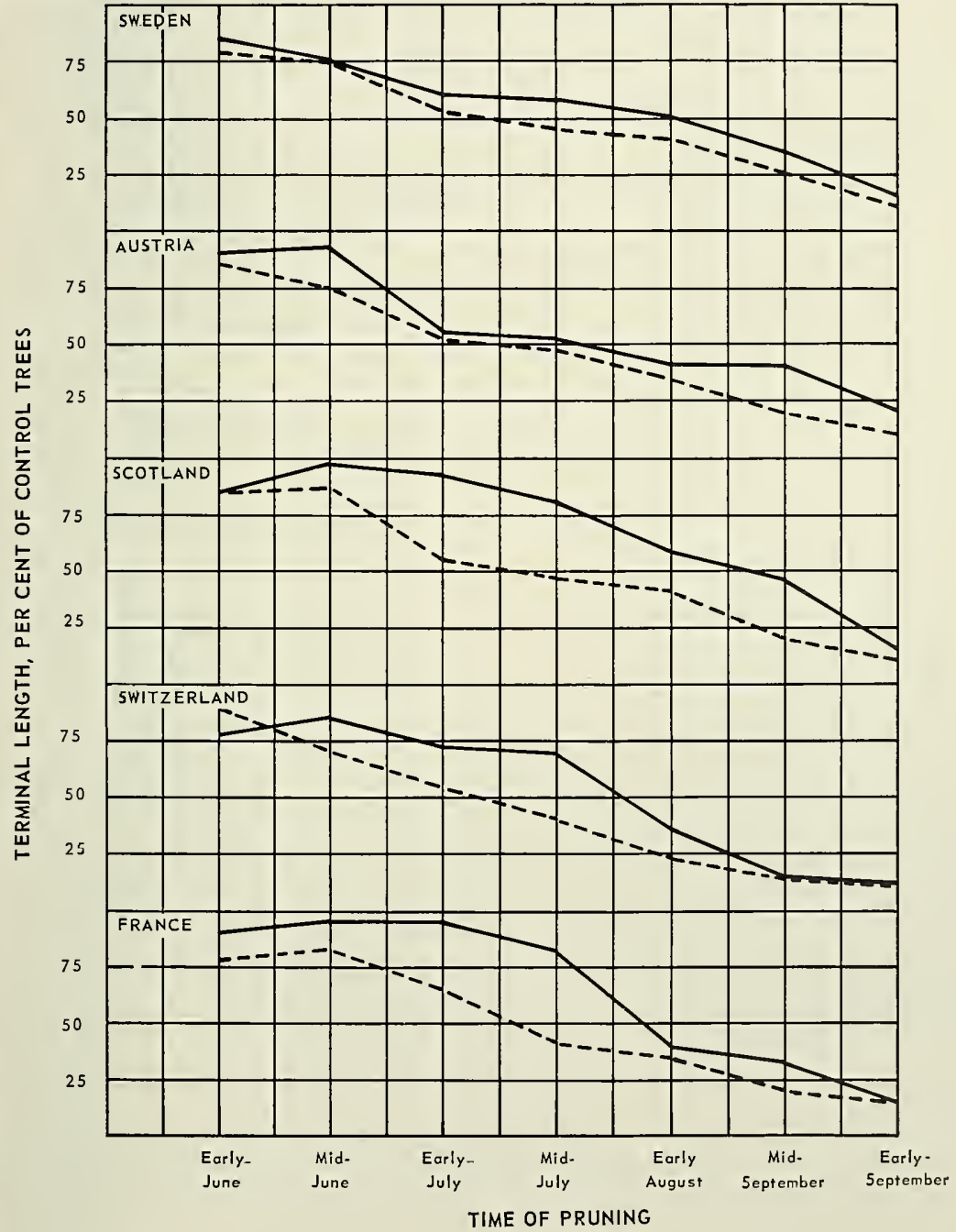


denced by the year-seed source and year-seed source-time interactions (Appendix Table 1). Figure 6A illustrates this, where it may be seen that the later growing season in 1961 (Table 3) resulted in considerably greater growth after mid- to late-summer prunings of the more southerly French, Swiss, and Scottish origins than was the case with the Swedish and Austrian source trees.

\section{DISCUSSION}

The different patterns of effective limb and terminal development outlined for the Scotch pine origins used in this study can be quite important to the Christmas tree grower. A number of studies have pointed out that there is a rather limited period during which optimum results can be obtained from shearing of pines, including Scotch pine. The study reported here further shows that this optimum time of pruning is not the same for all seed sources of Scotch pine, nor is it the same every year.

A definite trend was illustrated, showing that the more southerly the origin of the seed of Scotch pine, or possibly the higher the average annual temperature of the place of origin, the better are the results from prunings made during mid- to late-summer. This can be of importance to the grower, for if he is working with a northern origin, such as the Swedish one used here, it would be best to complete pruning of the trees quite early in the summer. However, if areas from a more southerly origin are being used, such as those from the Central Massif of France, the grower can logically expect to obtain reasonably good results from prunings made somewhat later, say up to early- to mid-July, with the exact results depending on the particular year. This added two weeks to a month during which results of pruning can be expected to be at or near optimum can be very helpful, particularly if the grower has a large number of trees which must be sheared.

These factors can also be important in working with young trees which are just coming up to a height where pruning is needed. If a northern origin is pruned in early-June, for example, growth the following year might well be only 55 to 60 per cent that on unpruned trees (Figure 6B). If trees just becoming large enough to be sheared would normally grow only 12 to 16 inches without pruning, growth the year after pruning might be so greatly reduced as to leave terminals which were not large enough for pruning in the second year. In working with a southern source, however, growth after an early-July pruning might be expected to be considerably greater, say from 70 to 90 per cent (Figure $6 \mathrm{~B})$ of that on unpruned controls. In this case, shoot growth on smaller trees the year after pruning might still be sufficient to allow for normal pruning the second year. 

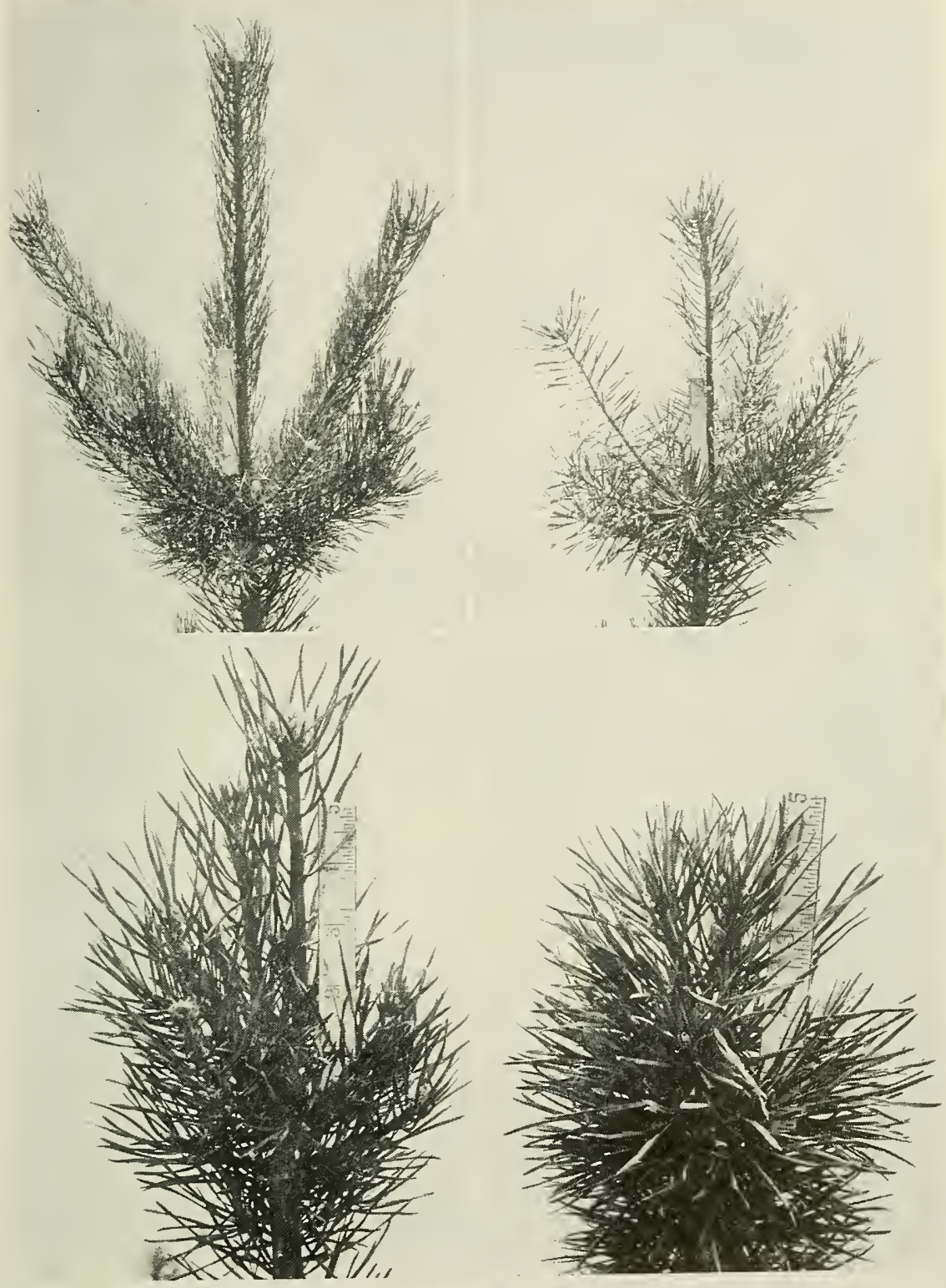

FIGURE 7

Terminal growth in Scotch pine pruned at four different times during the summer. The tree at the top left was pruned in early-June; the one at the top right was pruned in early-July; the one at the bottom left was pruned in earlyAugust; and the one at the bottom right was pruned in early-September. 
There is a logical explanation why results of prunings vary in the manner that they do. Brown (1964) showed that results of shearing are well correlated with stage of development of the cut stems, and that optimum results are obtained if shearing is done at the time when new shoots begin to harden-off. A number of studies have shown that the exact growth pattern of trees will vary with seed source, and generally that the more southerly origins of a given species grow somewhat later in the summer than do northern origins of the same species. For example, Santamour (1960) in working with eastern white pine (Pinus strobus L.) found that a source originating from Quebec had completed terminal shoot growth by May 25, 1959, a Minnesota origin did not complete shoot growth until June first, and that the most southerly origin used, one from Georgia, grew until June 15. Wright and Bull (1963) reported variation of over two montls in date of first year bud formation between the most northerly and southerly sources of Scotch pine used in their study, with north-Scandanavian trees forming terminal buds in mid-June, while Spanish sources did not form terminal buds until early-September.

In 1963, periodic measurements of terminal elongation taken on trees from the plantation used in this study showed pronounced differences in both growth patterns and length of growth period of Scotch pine. As shown in Table 5 and Figure 8, terminal elongation on Swedish source trees was slowing down by late May and was essentially completed by mid-June. Trees of the French source, on the other hand, were still growing quite rapidly in height until after mid-June and total elongation was not completed until approximately the first of july. The other three sources had completion dates for shoot growth which were intermediate between these two, but which were fairly well correlated with latitude or climate of origin. For example, the Austrian source showed the greatest total growth in 1963, but an examination of the growth curves indicated that elongation had begun to slow down by approximately the third week in June and was completed by about June 25 . The Scottish and Swiss sources, on the other hand, had less total elongation, but apparently grew somewhat longer.

The exact growth patterns were also quite interesting. The Swedish source showed the most rapid initial growth, but as indicated previously, began to slow down and completed growth quite early. French source trees, however, started elongation somewhat more slowly, as shown in Table 5 and Figure 8, finally equaled the growth on Swedish trees about the tenth of June, and then continued shoot elongation considerably later into June or early-July, with total growth for the season being nearly 25 per cent greater than that on the Swedish source trees. The Austrian trees showed still a third pattern of terminal growth, with rapid 


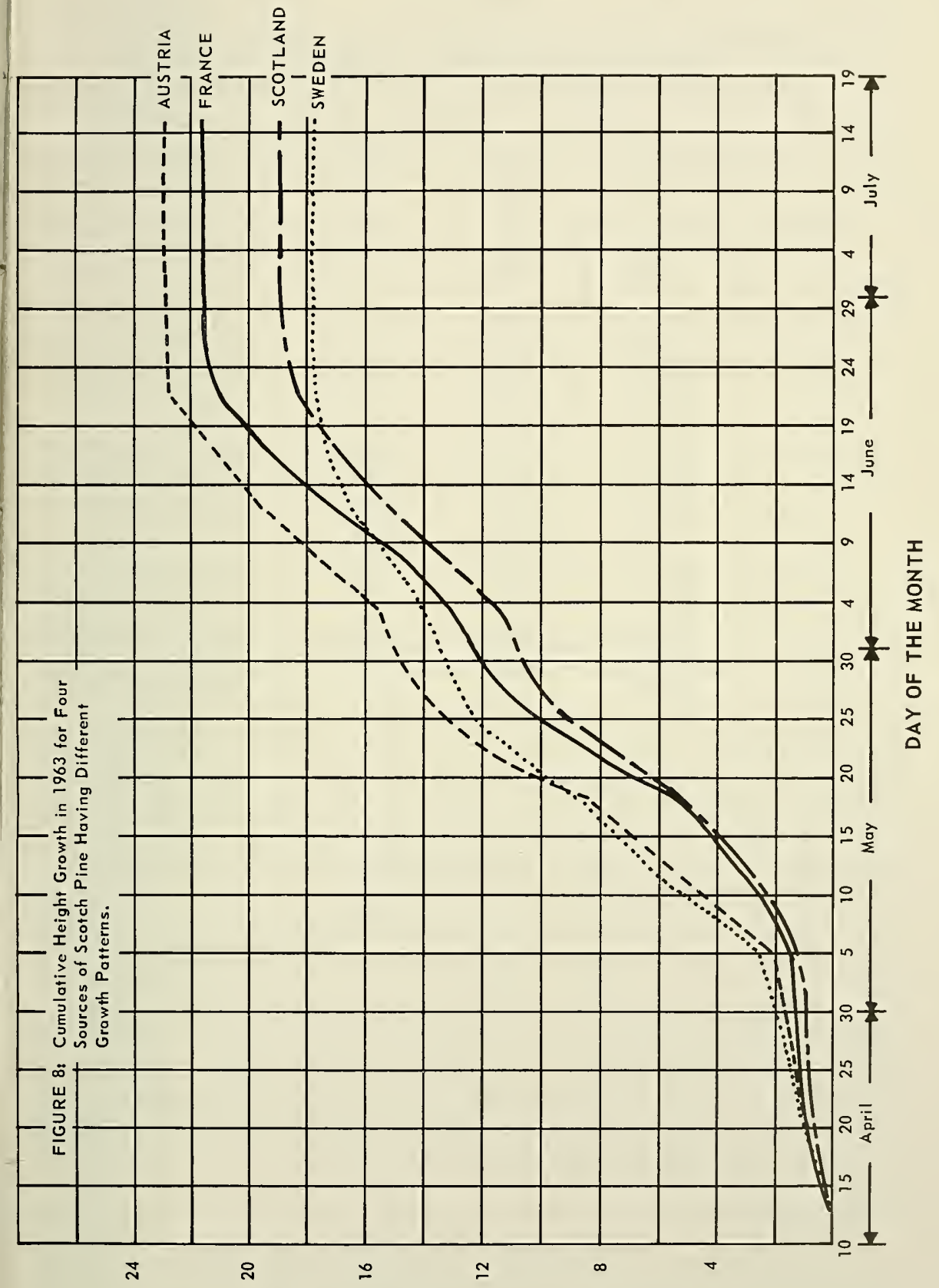

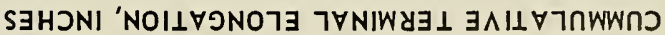


TABLE 5

\section{Cumulative height growth of five geographic origins of Scotch Pine during the summer of 1963}

\begin{tabular}{|c|c|c|c|c|c|}
\hline \multirow[b]{2}{*}{ Date } & \multicolumn{5}{|c|}{ Cumulative Terminal Elongation in Inches for Source } \\
\hline & Sweden & Austria & Scotland & Switzerland & France \\
\hline $\begin{array}{r}\text { April } 12 \\
16 \\
20 \\
23 \\
27\end{array}$ & $\begin{array}{l}0.00 \\
0.39 \\
0.91 \\
1.35 \\
1.65\end{array}$ & $\begin{array}{l}0.00 \\
0.42 \\
0.92 \\
1.17 \\
1.40\end{array}$ & $\begin{array}{l}0.00 \\
0.41 \\
0.69 \\
0.81 \\
0.90\end{array}$ & $\begin{array}{l}0.00 \\
0.57 \\
0.96 \\
1.14 \\
1.42\end{array}$ & $\begin{array}{l}0.00 \\
0.55 \\
0.86 \\
0.98 \\
1.12\end{array}$ \\
\hline $\begin{array}{l}\text { May } 5 \\
11 \\
18 \\
21 \\
25 \\
29\end{array}$ & $\begin{array}{r}2.60 \\
5.80 \\
8.73 \\
10.40 \\
12.29 \\
13.09\end{array}$ & $\begin{array}{r}2.12 \\
4.89 \\
8.30 \\
10.80 \\
13.25 \\
14.45\end{array}$ & $\begin{array}{r}1.17 \\
2.63 \\
4.97 \\
7.80 \\
9.23 \\
10.35\end{array}$ & $\begin{array}{r}2.16 \\
4.79 \\
7.68 \\
9.60 \\
11.81 \\
12.86\end{array}$ & $\begin{array}{r}1.49 \\
2.83 \\
5.33 \\
7.80 \\
10.01 \\
11.69\end{array}$ \\
\hline $\begin{array}{r}\text { June } \\
\quad 8 \\
12 \\
17 \\
22 \\
22 \\
26 \\
30\end{array}$ & $\begin{array}{l}13.93 \\
15.25 \\
16.52 \\
17.33 \\
17.68 \\
17.68 \\
17.68\end{array}$ & $\begin{array}{l}15.40 \\
17.64 \\
19.42 \\
21.10 \\
22.74 \\
22.85 \\
22.85\end{array}$ & $\begin{array}{l}11.28 \\
13.21 \\
15.06 \\
16.90 \\
18.33 \\
18.72 \\
18.84\end{array}$ & $\begin{array}{l}14.20 \\
15.33 \\
16.66 \\
17.85 \\
18.37 \\
18.46 \\
18.50\end{array}$ & $\begin{array}{l}12.90 \\
14.73 \\
16.93 \\
19.18 \\
21.04 \\
21.51 \\
21.80\end{array}$ \\
\hline $\begin{array}{r}\text { July } \quad 2 \\
5 \\
8 \\
16\end{array}$ & $\begin{array}{l}17.68 \\
17.68 \\
17.68 \\
17.68\end{array}$ & $\begin{array}{l}22.85 \\
22.85 \\
22.85 \\
22.85\end{array}$ & $\begin{array}{l}18.84 \\
18.84 \\
18.84 \\
18.84\end{array}$ & $\begin{array}{l}18.50 \\
18.50 \\
18.50 \\
18.50\end{array}$ & $\begin{array}{l}21.85 \\
21.85 \\
21.85 \\
21.85\end{array}$ \\
\hline
\end{tabular}

initial elongation, similar to that of the Swedish source, and then continuing later into the summer, similar to that of the French trees, but with an earlier completion date for total growth. It is interesting to note that this source, the Austrian, with rapid initial and later summer growth, is the one displaying greatest total elongation of nearly one-third more than that on Swedish trees. The Swiss source trees showed a pattern similar to that of the Swedish ones with fast initial growth and slowing down fairly early, but they appeared to continue growing slowly for about two weeks or so longer than the Swedish source trees. This latter factor probably accounts for the better results from later summer prunings on Swiss as compared with Swedish trees. The Scottish source used showed still another variation, with slow initial growth, similar to the French source, but slowed down early and continued slow growth similar to that described for the Swiss trees.

\section{SUMMARY}

The importance of Scotch pine as a Christmas tree has been increasing steadily and at present more Scotch pines are sold for this purpose than trees of any other species. The natural range of Scotch pine occupies 
a large geographic area in Europe and Asia and there is a great deal of variation in characteristics of the species including growth rates, length of the growing season, foliage characteristics, and others. A number of studies have shown that results of pruning of Scotch pine may vary considerably depending upon the time of year when the shearing is carried out. The study reported here was initiated in order to determine if differences could be detected in results from pruning of different geographic origins of Scotch pine at various times during the summer.

Trees from five origins (Sweden, Austria, Scotland, Switzerland, and France) were pruned bi-monthly during the summers of 1961 and 1962, beginning in early-June and continuing until early-September. In general it was found that results of pruning showed distinct differences which were dependent not only upon the time when shearing was conducted, but also upon the seed source being sheared and the year in which pruning was carried out. Patterns of effective limb development and shoot elongation were developed for the different seed sources which appeared to be well correlated with latitude, or possibly climate, of origin.

Prunings of southern sources, such as those from France and Scotland, and possibly Switzerland, made during mid- to late-summer generally gave better results when compared to control trees than did comparably timed prunings made on the more northerly Austrian and Swedish source trees. Although exact results varied from year to year, the southern sources usually showed an increase in numbers of limbs or shoot growth after early- to mid-June or early-July prunings, with decreasing numbers or growth on trees pruned later. On northern sources results were generally best after early- to mid-June shearings, with decreasing numbers or growth on trees pruned later in the summer.

Exact patterns for effective limbs and terminal shoot growth were found to be similar, except that maximum shoot growth was usually found on trees pruned approximately two weeks earlier in the year than those on which maximum numbers of limbs were found.

Variations between years were found which were associated with prevailing weather conditions, particularly those during the early part of the growing season (early April to mid- or late-May). A particularly cold spring, such as that which occurred in 1961, resulted in a shift of maximum shoot development to a period somewhat later in the summer. It might also be speculated that an unusually warm spring might give a similar shift in optimum results to a time somewhat earlier in the year, a conclusion that is in keeping with results from an earlier study by Brown (1964) on Scotch pine of an unknown seed source.

Results of pruning of different sources were found to be correlated with the length of the height growth period of the Scotch pine sources 
used. Periodic shoot growth measurements made during the summer of 1963 revealed that French source trees did not complete terminal elongation until at least ten days after those of the Swedish source, and that trees of the other three sources had dates for completion of shoot growth which were intermediate between the French and Sivedish source trees.

\section{LITERATURE CITED}

Brown, James H. 1960. Fall and winter pruning of pines. W. Va. Univ. Agr. Exp. Sta. Current Report 26. 7 pp.

_-_ 1961. Slope of flat pruning of pines-an important consideration in Christmas tree plantation management. Journal of Forestry 59: 213-214.

--- 1964. Effect of time of summer pruning on bud set, limb development and shoot growth of sheared pines. W. Va. Univ. Agr. Exp. Sta. Bull. 498.33 pp.

Larsson, H. C. 1961. The shaping of pine trees by pruning and shearing. American Christmas Tree Growers' Journal, Vol. V, No. 2: 10-14. 32-34.

Santamour, Frank S. Jr. 1960. Seasonal growth in white pine seedlings from different provenances. Northeastern Forest Exp. Sta. For. Res. Note 105. 4 pp.

Sowder, A. M. 1961. Christmas tree data. Journal of Forestry 59: 829-830.

--_ 1963. Christmas tree data for 1962. Journal of Forestry 61: 869-871.

-_- 1965. The 1964 Christmas tree data. Journal of Forestry 63: 776-778.

United States Weather Bureau, Climatological Data, West Virginia Section. 1957 to 1966.

Wright, Jonathan W. and Henry I. Baldwin. 1957. The 1938 international union Scotch pine provenance test in New Hampshire. Silvae Genetica 6, Heft 1/2, 1-64. 14 pp.

Wright, Jonathan W. and W. Ira Bull. 1963. Geographic variation in Scotch pine. Results of a 3-year Michigan study. Silvae Genetica 12, Heft 1, 1-40. 25 pp.

\section{APPENDIX TABLE 1}

\section{Analyses of variance for numbers of effective limbs and terminal shoot growth on pruned stems of Scotch Pine}

\begin{tabular}{|c|c|c|c|c|c|}
\hline \multirow[b]{2}{*}{$\begin{array}{l}\text { Source of } \\
\text { Variation }\end{array}$} & \multirow[b]{2}{*}{$\begin{array}{c}\text { Degrees of } \\
\text { Freedom }\end{array}$} & \multicolumn{2}{|c|}{ Effective Limbs ${ }^{1}$} & \multicolumn{2}{|c|}{ Terminal Shoot Growth } \\
\hline & & $\begin{array}{l}\text { Mean } \\
\text { Square }\end{array}$ & $\begin{array}{l}\text { Value of } \\
\text { "F" }\end{array}$ & $\begin{array}{c}\text { Mean } \\
\text { Square }\end{array}$ & $\begin{array}{c}\text { Value of } \\
\text { "F" }\end{array}$ \\
\hline Replications (R) & 4 & 0.1950 & & 6.9280 & \\
\hline $\begin{array}{l}\text { Time of Pruning } \\
\text { During Summer (T) } \\
\text { Error a (RxT) }\end{array}$ & $\begin{array}{r}7 \\
28\end{array}$ & $\begin{array}{r}15.2400 \\
0.0564\end{array}$ & 270.21 & $\begin{array}{c}1842.2800 \\
4.498\end{array}$ & 409.58 ? \\
\hline Seed Source (S) . . & 4 & 0.3550 & $5.61^{\circ \circ}$ & 41.3720 & $9.996^{\circ \circ}$ \\
\hline $\begin{array}{l}\text { Seed Source } x \text { lime } \\
(\text { Sx'T) } \ldots \ldots \ldots \ldots \\
\text { Error b }\end{array}$ & 28 & 0.1930 & $3.05^{\text {o }}$ & 14.7290 & $3.559^{\circ \circ}$ \\
\hline$(\mathrm{RxS}+\mathrm{RxSxT}) \ldots$ & 128 & 0.0633 & . & 4.139 & \\
\hline Year of Pruning (Y) & 1 & 5.9000 & $97.36^{\circ \circ}$ & 233.020 & $49.589^{\circ \circ}$ \\
\hline $\begin{array}{l}\text { Year } x \text { Time }(\mathrm{Y} x \mathrm{~T}) \\
\text { Error c } \\
(\mathrm{RxY}+\mathrm{RxY} \mathrm{X})\end{array}$ & 32 & 0.0606 & $10.33^{\circ}$ & 4.699 & $8.124^{\circ}$ \\
\hline Year $x$ Source (YxS). & 4 & 0.0525 & 1.17 & 28.088 & $8.101^{\circ \circ}$ \\
\hline $\begin{array}{l}\text { Year } x \text { Source } x \text { Time } \\
\text { (YxSxT) } \ldots \ldots \ldots \ldots\end{array}$ & 28 & 0.746 & $1.67^{\circ}$ & 7.765 & $2.240^{\circ}$ \\
\hline $\begin{array}{l}\text { Error d } \\
\left(\operatorname{RxYxS}+\mathrm{RxYxSx}^{\top} \mathrm{T}\right) .\end{array}$ & 128 & 0.0448 & & 3.467 & \\
\hline Total & 399 & & & & \\
\hline
\end{tabular}

${ }^{3}$ Enumeration data for effective limbs transposed by $\sqrt{\mathrm{X}+1}$ before analysis.

-Denotes statistical difference at 5 per cent level.

- oDenotes statistical difference at 1 per cent level. 

10.9.

10.

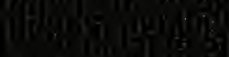

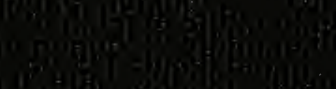

alding

ji, ming

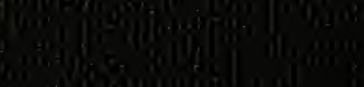

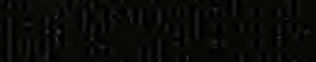

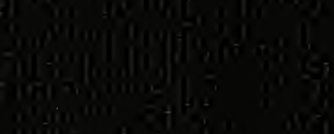

Q ît.

action

Hio

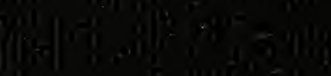

instions

stong

$6 x^{2}$ 